fázi pražských univerzitních dějin a zájemci o hlubší poznání minulosti pražské univerzity pak podává přehled základních a klíčových problémových okruhů její podoby v nejstarším období. V obou směrech se dostává čtenáři do ruky špičkový výkon českého dějepisectví posledního padesátiletí, který bude, troufám si tvrdit, v dohledné době jen stěží překonán.

doi: $10.14712 / 23365730.2018 .43$

\title{
Elisabeth Tuisl, Die Medizinische Fakultät der Universität Wien im Mittelalter. Von der Gründung der Universität 1365 bis zum Tod Kaiser Maximilians I. 1519 \\ V\&R unipress, Vienna University Press, Göttingen 2014, 366 s., 13 čb vyobrazení, ISBN 978-3-8471-0330-1 a 978-3-8470-0330-4 (e-book)
}

K sepsání zprávy o knize uvedené v titulu přistupuji s jistými rozpaky jednak proto, že publikace je již tři roky stará, a jednak proto, že se jedná o dílo chronologicky zapadající do období, kterému se nevěnuji. Jedná se však o počin zcela mimořádného významu pro dějiny univerzit ve střední Evropě a také pro dějiny medicíny, který by měl být na stránkách tohoto odborného časopisu zmíněn. Čtenářům HUCP zde tudíž předkládám pouhou zprávu s minimem hodnotících prvků a doufám, že se v budoucnosti někdo ujme důkladné recenze.

Jak název napovídá, máme před sebou monografii, jejímž základem byla diplomová práce Elisabethy Tuislové z roku 2008, kterou dále doplnilo důkladné studium ve vídeňském univerzitním archivu. Publikace má dvě hlavní části - historickou a prosopografickou.

Historická část je dále rozdělena do sedmi oddílů. První poskytuje obecný rámec k vlastnímu předmětu monografie a začíná stručným přehledem vývoje medicíny od antiky přes klášterní medicínu a arabské vlivy ve středověku až po popis vlny zakládání lékařských fakult na evropských univerzitách. Druhý oddíl se zabývá založením Vídeňské univerzity $\mathrm{v}$ roce 1365, poté na základě zachovaných statut podrobně rozebírá, co je známo o organizaci její lékařské fakulty. Ve třetím oddíle se dozvíme něco o historickém nemovitém majetku fakulty kolejemi počínaje přes špitál a knihovnou konče.

Následující oddíl, který je nesmírně zajímavý pro právě probíhající výzkum o dějinách vzdělanosti v Čechách, si klade otázku, jak probíhala výuka medicíny ve Vídni. Není to př́lišs známo, ale Vídeňská univerzita má patrně nejstarší tiskem vydaný přehled o přednáškách a obsahu studia v Evropě. Jedná se o Liber de modo studendi seu legendi in medicina profesora Martina Stainpeise z roku 1520. Tento text je zvláště cenný tím, že v celém 16. století vyšlo v Evropě jen několik podobných tisků a že zachycuje situaci na nám blízké Vídeňské univerzitě. V Čechách vznikla publikace s podobným obsahem (odhlédneme-li od krátké řeči na obhajobu výuky anatomie vydané na počátku 17. století Adamem Zalužanským ze Zalužan) až na samém konci 17. století díky Janu Františku Löwovi z Erlsfeldu.

Pátý oddíl představuje pokus o rekonstrukci chronologického vývoje dějin lékařské fakulty nejprve odděleně ve 14. století. Zde autorka akcentovala osobu Mistra Galeazza de Santa Sofia a také osoby spojující Vídeň s významnými evropskými fakultami. Na tomto místě je potřeba upozornit, že se jedná, s ohledem na sporé prameny, o velice stručnou 
pasáž, většinou doslova jen seznam jmen studentů, kteří studovali například v Padově a posléze se objevili také v Rakousku.

Předposlední oddíl této části má rozsah třicet stran a je věnován vztahu mezi fakultou a společností, tedy např́klad tématu studentského života, dohledu nad lékaři, boji proti neakademickým zdravotním profesím (léčitelé, mastičkáři, Židé, báby kořenářky atd.) a také podílu na regulaci lékárnické profese ve Vídni. Sedmý oddíl pak prrináší přehled známé publikační činnosti vídeňských lékařů a profesorů.

Druhá část knihy je neméně důležitá, jedná se totiž o biografický slovník vídeňské fakulty, tedy zdroj, který mají pro Lékařskou fakultu Univerzity Karlovy naši čtenáři dostupný již více než dvacet let. Stejně jako je český biografický slovník rozdělen podle etap vývoje Univerzity Karlovy, i dílo E. Tuislové rozlišuje určitá období v dějinách fakulty a teprve v jejich rámci jsou zpracované osoby uspořádány dle abecedy. První etapa zaznamenává dobu před ustavením univerzitních akt v roce 1399, druhá pak zahrnuje osoby z let 13991519. V obou částech je nejprve trochu nadbytečný seznam osob a pak abecedně řazená prosopografická část s hesly zpracovanými podobně jako v českém slovníku.

Na závěr ještě najdeme přehled lékařủ, kteří studovali v zahraničí a ve Vídni byli nostrifikováni, index místních jmen a přívlastků osob, seznam zkratek či obligátní seznam pramenů a literatury.

Ačkoli jsem na počátku tohoto stručného popisu monografie E. Tuislové konstatoval, že zde nepíšu recenzi, neodpustím si poznámku, že mi v seznamu pramenů chybí odkaz na obsáhlé biblio- a biografické dílo Scriptores antiquissimae ac celeberrimae universitatis Viennensis z let 1740-1742, které by jako Tuislové duchovní předchůdce mělo být alespoň zmíněno, a dále - a to považuji za závažnější opomenutí - Tuislová nezná český biografický slovník, s nímž jsem její dílo v předchozích odstavcích srovnával. 